J. Perinat. Med. 15 (1987) 415

\section{Actual state in the diagnosis of fetal lung maturity}

\author{
Uwe Lorenz, Volker Ragosch, and Hans K. Weitzel \\ Department of Obstetrics and Gynecology, University Clinic Steglitz, Free Univer- \\ sity of Berlin, West Germany
}

\section{Introduction}

More than one decade has passed since GLUCK et al. [4], based on preceding work of E. SCARPELLI $[12,13]$ could show the interrelationship between phospholipids, detectable in human amniotic fluid, and the respiratory distress syndome (RDS) of the newborn. The change in concentration of various phospholipids, in particular of lecithin and sphingomyelin, or the ratio of both, takes place according to the progress of gestation with a sharp rise in lecithin concentration at about 35/ 36 weeks. Simultaneously the incidence of neonatal RDS declines [2]. Nowadays, the problem of lowering neonatal mortality is reduced to the problem of mortality of preterm born infants, whose main cause of death remains up to now the respiratory distress syndrome.

There is still no effective prevention of prematurity by means of tocolysis in sight, so in the science and clinical practice, three main routes of investigation have been followed by obstetricans and neonatologists:

- Evaluation of fetal lung maturity by amniotic fluid analyses;

- Antenatal pharmacological treatment of the fetus in cases with known or supposed lung immaturity: in some way a sort of preventive treatment;

- Postpartum treatment of neonates with obvious lack of sufficient surfactant.

Different ways for the determination of fetal (lung) maturity have been walked on: biophysical, cytological, physiological and biochemical ones. Each of the various methods uses different fetal parameters, which change with advancing intrauterine development and maturation of the un-

\section{Curriculum vitae}

UWE LORENZ, M.D. was born on April 5, 1945 in Marburg/Lahn. From 1963-1969 he studied medicine at the universities of Mainz, Hamburg and Frankfurt and received his doctoral degree in 1969. He spent one year at the Institute of Pharmacology in Munich and was a resident at the department of

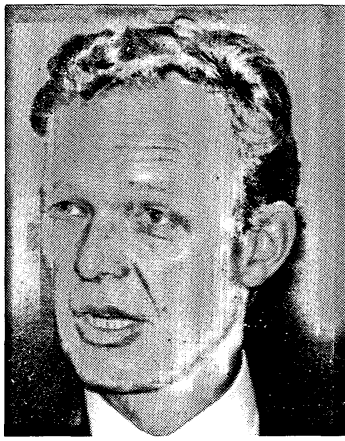
obstetrics and gynecology in Heidelberg from 1971 to 1978 (Head: Prof. Dr. F. KUBLI). He qualified as a university lecturer in 1980 and has been on the staff of the University Women's Hospital Steglitz in Berlin since 1985 (Head: Prof. Dr. H. WEITZEL). His main scientific interests include perinatology, gynecological oncosurgery and reconstructive breast surgery.

born child. Biophysical methods measure the surface tension lowering ability of surfactant fragments in amniotic fluid [11]; cytological methods show changes in the composition and properties of amnion epithelial cells; physiological methods deal with changes in the procoagulatory activity under the influence of rising phospholipid levels [7] or with changes in microviscosity [9] and finally the biochemical methods deal with changes in concentration of various phospholipids in amniotic fluid, which originate from the fetal lung and which are essential parts of the fetal lung surfactant.

Our data will show which biochemical methods can be used in daily practice by the obstetrical clinics. 


\section{Material and methods}

One hundred forty eight amniotic fluid samples from 130 patients, obtained either by transabdominal amniocentesis or by vaginal sampling after premature rupture of membranes were analyzed. In about $2 / 3$ of the samples $(n=96)$ the time interval between amniotic fluid collection and delivery was below $72 \mathrm{hrs}$. This period of time is important if any correlation between test result and respiratory status of the newborn is looked for.

The following methods of phospholipid analysis in amniotic fluid were used:

- A miniaturized version of an one-dimensional thin layer chromatographic determination of the lecithin/sphingomyelin ratio [5];

- A one-dimensional thin layer chromatographic separation of all phospholipid components in amniotic fluid [3];

- A completely emzymatic determination of amniotic fluid lecithin concentration $[1,10]$;

- An immunological method for semiquantitative measurement of phosphatidylglycerol [8].

The method for L/S ratio determination (miniaturized version) is published elsewhere [9]. By sequential one-dimensional development with two different solvent mixtures Sph, Lec, PI, PE, PS and PG can be separated. Evaluation is made visually or densitometrically by comparison with standards of known $\mathrm{L} / \mathrm{S}$ ratio $(2: 1,1.5: 1,1: 1)$ and by evaluation of presence or absence of phosphatidylglycerol and the other phospholipids (PI, PE, PS) (table I).

In the enzymatic determination of lecithin, after enzymatic cleavage of phosphatidylcholine by phospholipase $\mathrm{C}$ and cleavage of phosphorylcholine to choline and phosphate by alkaline phosphatase, choline is used as a substrate of a two step enzymatic cascade with leads to the determination of the consumption of $\mathrm{NADH}$, that can be measured easily at wavelength 365 and $334 \mathrm{~nm}$. The amnount of NADH consumption is equimolar to choline and thus to lecithin (figure 1).

The immunological determination of phosphatidylglycerol is based on the precipitation of PG by PG-antibodies, prepared in rabbits (Reagent B), in presence of an ethanolic solution of egg yolk lecithin (Reagent A). By comparison to simultaneously processed PG-standards of known concentration (threshold value $2 \mathrm{mg} / \mathrm{l}$ ) the presence or absence of $P G$ in the patients pecimen can be confirmed.
Table I. Chart flow of one-dimensional sequential thin layer chromatographical separation of amniotic fluid phospholipids according to GIPs' procedure [3].

AF-sample
$\downarrow$
extraction
(chloroform/methanol $2: 1)$
evaporation of
organic phase
$\downarrow$
acetone precipitation
$\downarrow$
resolution of PL in chloroform
$\downarrow$
separation of PL on silica gel plates
by
solvent mixture I
$50 \quad$ ethylacetate : 2 -propanol : aqua dest
35
and

solvent mixture II

chloroform : methanol : ammonia 58\%

$65: 30: 3$

visualization of PL-fractions

by Phospray (sulfuric acid/ammonium molybdate)

evaluation of phospholipids

by planimetry (L/S ratio) and visual

estimation of the presence of minor

PL-fractions (PG, PJ, PE, PS)

\section{Results}

As to be expected a strong correlation exists between changes in $\mathrm{L} / \mathrm{S}$ ratio and advancing gestational age (figures 2, 3 and 4). Phosphatidylglycerol, determined chromatographically or immunologically, correlates well to gestational age (figure 5). Enzymatically determined lecithin concentrations shows the expected correlation of values according to advancing gestational age at both choosen wavelengths for photometric evaluation $(\lambda=365$ or $334 \mathrm{~nm}$ ) (figures $6 \mathrm{a}$ and $6 \mathrm{~b}$ ).

For comparison of the validity of the various methods in predicting neonatal RDS, 4-field contingency tables and $\chi^{2}$ test were used. Significant results in prediction of neonatal RDS we found using one-dimensional separation of PL for the $\mathrm{L} / \mathrm{S}$ ratio, as well as for the chromatographic or immunologic PG determination (table II). 

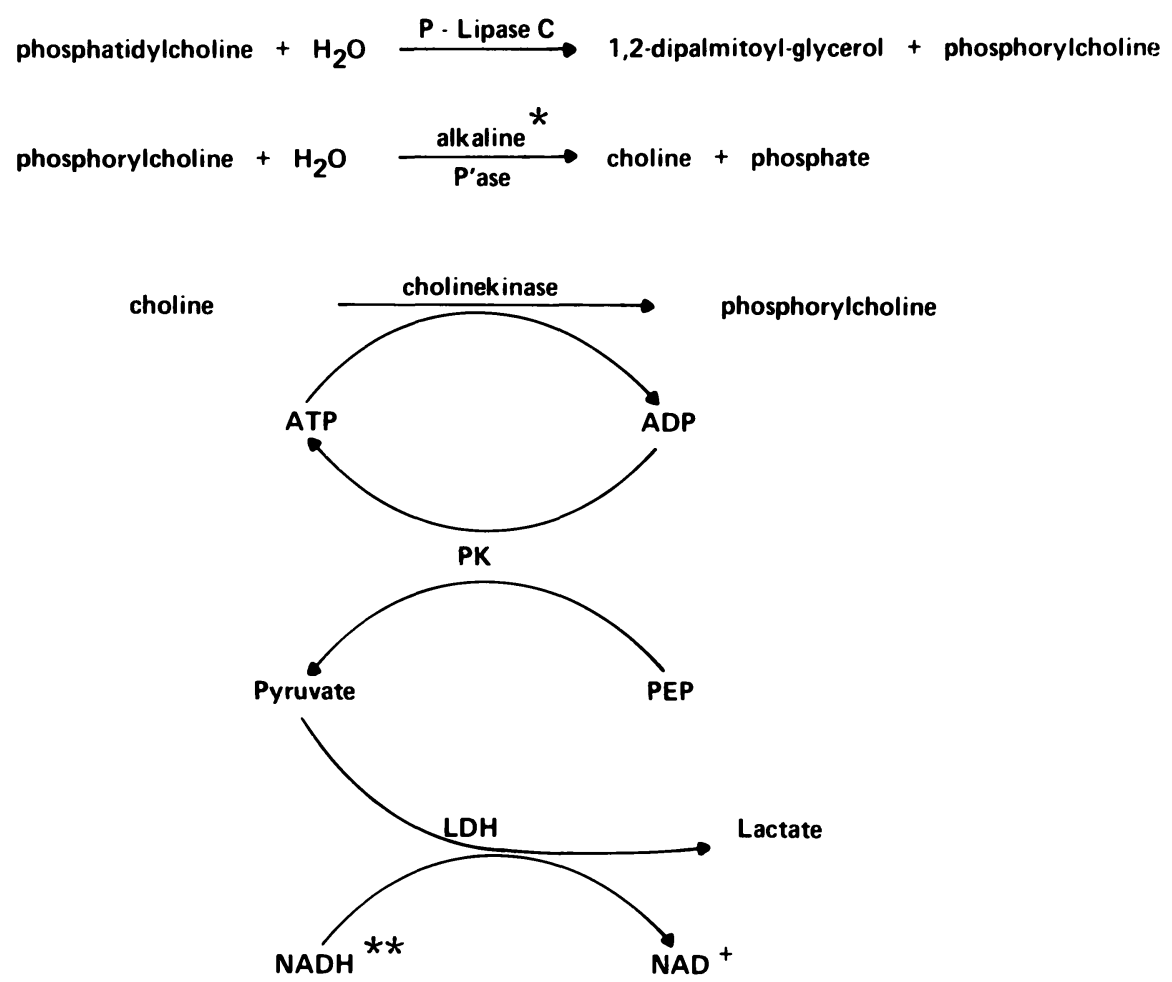

Figure 1. Assay principle of enzymatic determination of amniotic fluid lecithin; * inactivation at $95-100^{\circ} \mathrm{C}$, ** photometric measurement of NADH consumption at $\mathrm{Hg} 365 \mathrm{~nm}$ or $334 \mathrm{~nm}$.

Table II. Prediction of neonatal RDS by various methods of amniotic fluid phospholipid determination.

\begin{tabular}{lll}
\hline Method & $\varnothing$ RDS & RDS \\
\hline Miniaturized L/S ratio & & \\
$\quad$ L/S $>2$ & 13 & 2 \\
L/S $\leqslant 2$ & 13 & 6 \\
One-dimensional two step & & \\
TLC of phospholipids & & \\
$\quad$ L/S $>2$ & 43 & $0^{*}$ \\
L/S $\leqslant 2$ & 11 & $4^{*}$ \\
Enzymatic lecithin determ. at & & \\
$\lambda=365$ nm and $\lambda=334 \mathrm{~nm}($ ) & & \\
Lec $>5$ mg\% & $38(32)$ & $2(1)$ \\
Lec $\leqslant 5$ mg\% & $16(38)$ & $2(7)$ \\
Immunologically and & & \\
TLC ( ) evaluated PG & & \\
PG present & $40(33)$ & $1(0)^{*}$ \\
PG absent & $39(22)$ & $9(4)^{*}$
\end{tabular}

* indicates significant accordance of AF-PL-result to neonatal RDS
In this study material, for enzymatic lecithin and the miniaturized $\mathrm{L} / \mathrm{S}$ ratio determination we could not prove statistically significant results due to the small number of RDS cases, but this correlation has been confirmed for both methods in a larger report only recently [10]. For one dimensional thin layer chromatographic determination of $\mathrm{L} / \mathrm{S}$ ratio as well as for chromatographic or immunologic PG determination a clear correlation to the expected development of RDS in the newborn exists.

The validity of certain test methods has to be described by more than one biostatistical data, namely: sensitivity, predictive correctness of positive or negative result and specificity. The results of these data for the tests evaluated are shown in table III. Throughout all tests we find high values for sensitivity and for the predictive correctness of negative test, that is: good capability of the test to exclude the danger of impending RDS if the threshold value is trespassed. But in all four tests investigated, a low correctness of negative test is observed. 
A. Preparation of Lipid Particles $($ in $12 \times 75 \mathrm{~mm}$ glass tubes)

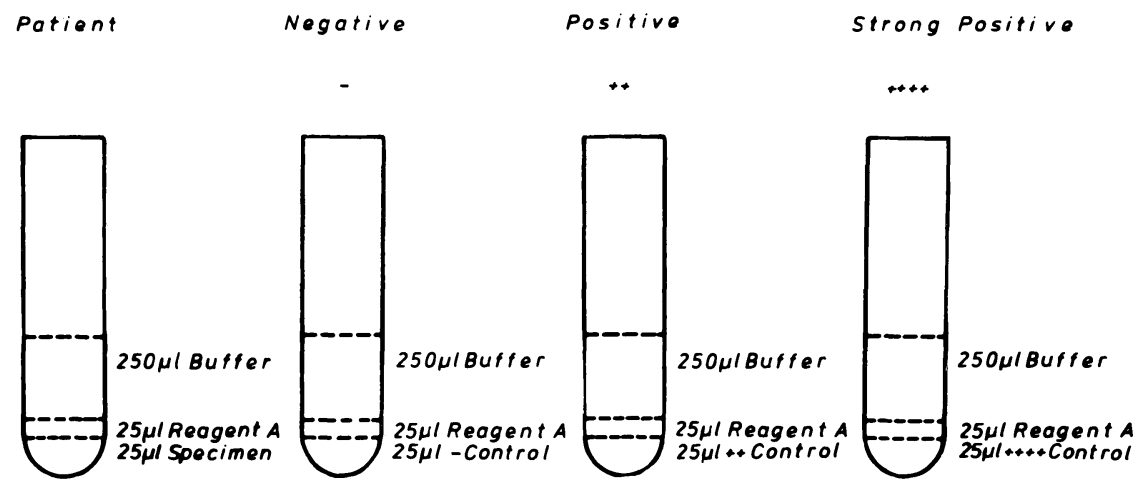

B. Preparation of Agglutination Reactions (on agglutination slide)

1. $25 \mu$ l Reagent $B$ in each ring

2. $10 \mu l$ of each suspension to appropriate ring

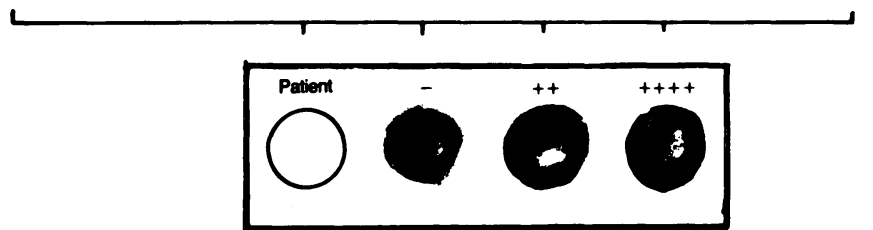

C. Incubation of Reaction Mixtures (Cover and rotate at $60 \mathrm{rpm}$ for $9 \mathrm{~min}$ )

\section{Examination of Completed Reactions}

Figure 2. Immunological determination of amniotic fluid phosphatidylglycerol: assay procedure.

Table III. Predictive values of various amniotic fluid phospholipid determination methods (for abbreviations see table II).

\begin{tabular}{|c|c|c|c|c|c|c|}
\hline & $\begin{array}{l}\mathrm{L} / \mathrm{S} \\
\text { 1-dim. } \\
\text { (miniat.) }\end{array}$ & $\begin{array}{l}\text { L/S } \\
\text { 1-dim. } \\
\text { 2 step }\end{array}$ & $\begin{array}{l}\text { Lec } \\
\text { enzym. } \\
\lambda=365 \mathrm{~nm}\end{array}$ & $\begin{array}{l}\text { Lec } \\
\text { enzym. } \\
\lambda=334 \mathrm{~nm}\end{array}$ & $\begin{array}{l}\text { PG } \\
\text { immun. } \\
\text { FLM }\end{array}$ & $\begin{array}{l}\text { PG } \\
\text { 1-dim. }\end{array}$ \\
\hline Sensitivity & $75 \%$ & $100 \%$ & $50 \%$ & $88 \%$ & $90 \%$ & $100 \%$ \\
\hline $\begin{array}{l}\text { Predictive correctness } \\
\text { of positive test }\end{array}$ & $32 \%$ & $27 \%$ & $11 \%$ & $16 \%$ & $19 \%$ & $15 \%$ \\
\hline Specificity & $50 \%$ & $80 \%$ & $70 \%$ & $46 \%$ & $51 \%$ & $60 \%$ \\
\hline $\begin{array}{l}\text { Predictive correctness } \\
\text { of negative test }\end{array}$ & $87 \%$ & $100 \%$ & $95 \%$ & $97 \%$ & $98 \%$ & $100 \%$ \\
\hline
\end{tabular}




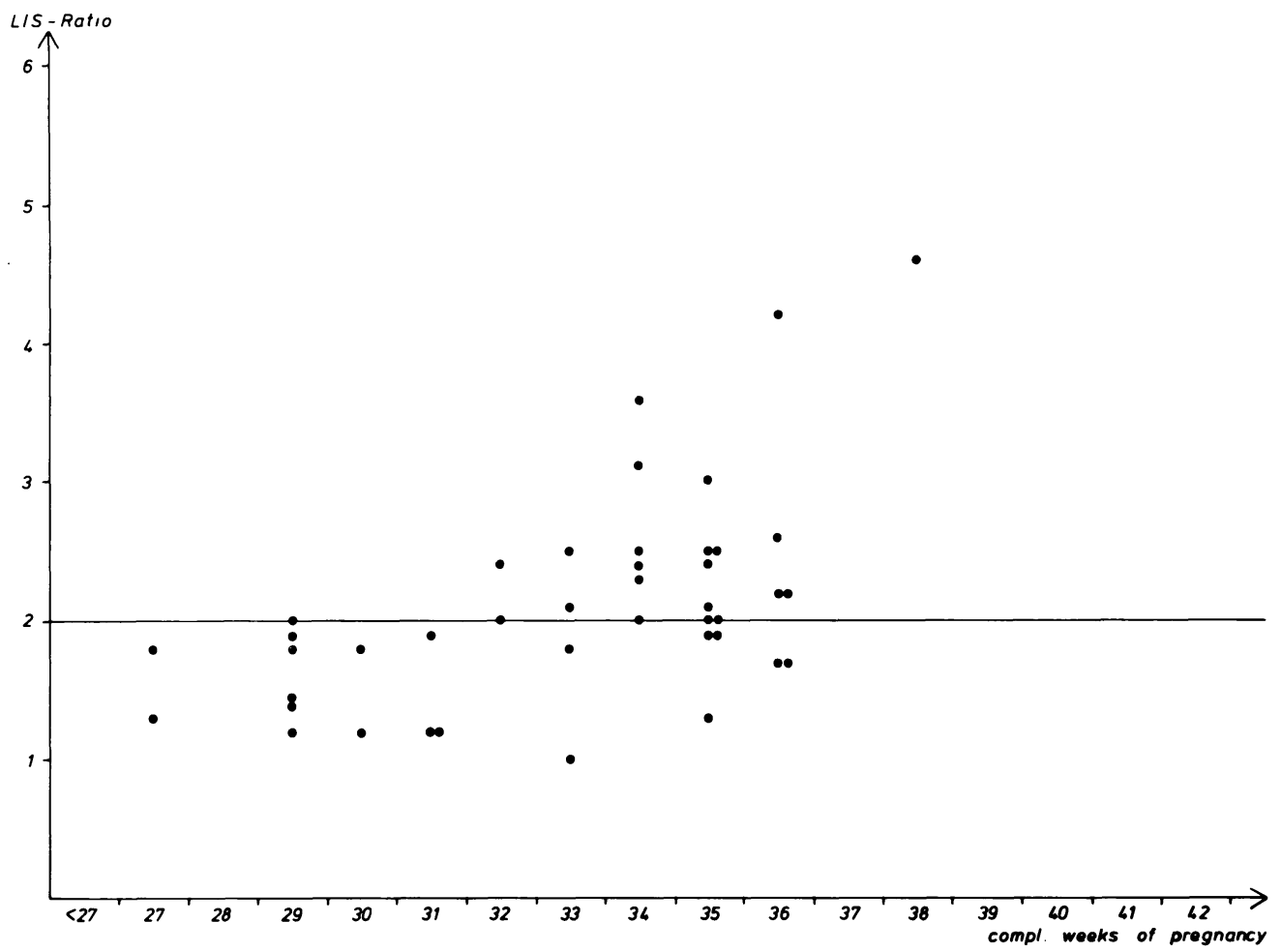

Figure 3. $\mathrm{L} / \mathrm{S}$ ratio values in amniotic fluid according to gestational age. Determination by a miniaturized one dimensional TLC-method [2]. Positive correlation of $\mathrm{L} / \mathrm{S}$ ratio values vs. gestational age $(29-38$ weeks): $\mathrm{y}=$ $0.174-3.632 ; \mathrm{r}=0.566$.

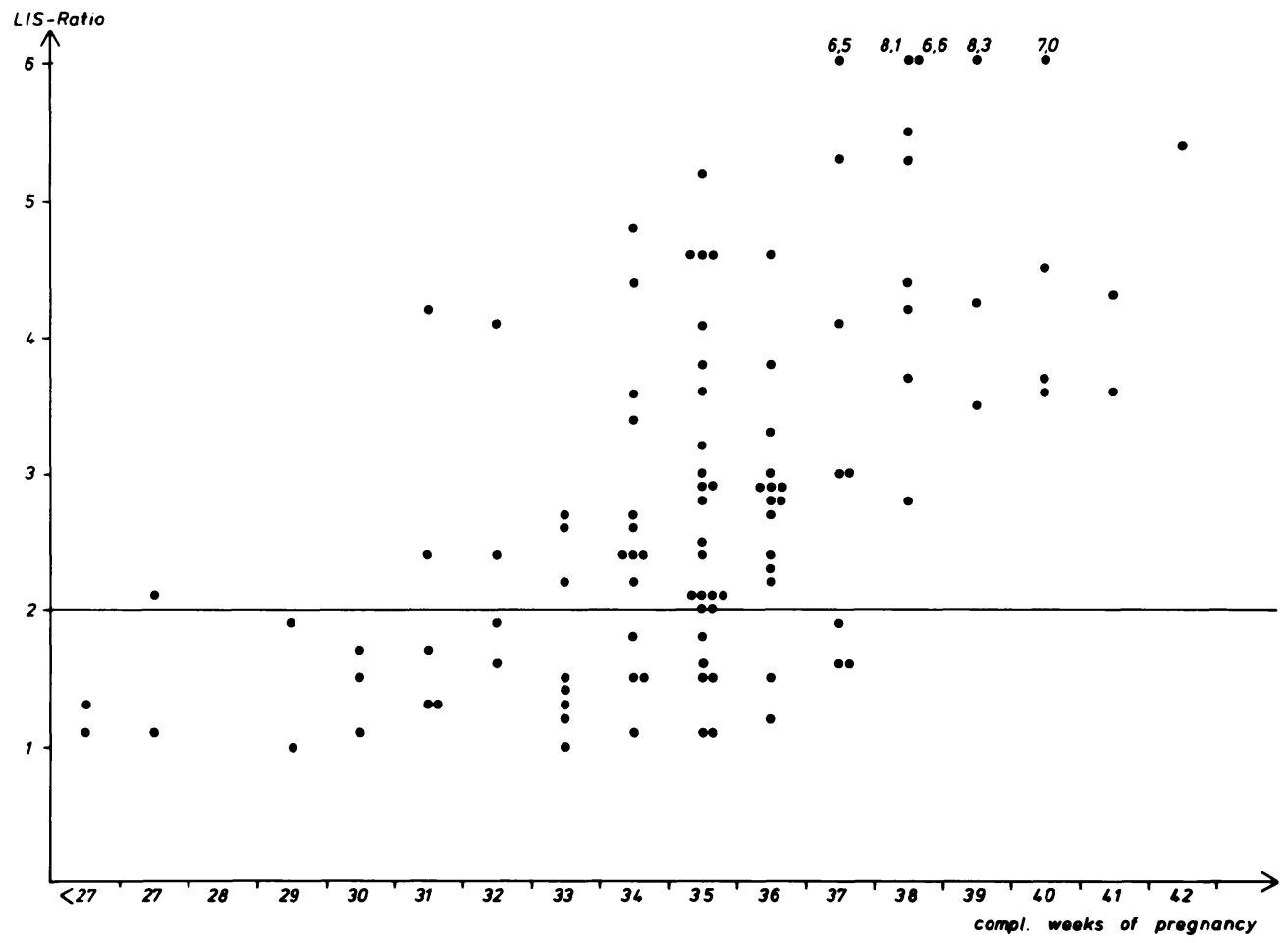

Figure 4. $\mathrm{L} / \mathrm{S}$ ratio values in amniotic fluid according to gestational age. Determination of $\mathrm{L} / \mathrm{S}$ ratio by one dimensional sequential two step TLC. Positive correlation of L/S ratio values vs. gestational age (33-39 weeks): $\mathrm{y}=9.536-16.01 ; \mathrm{r}=0.549$. 


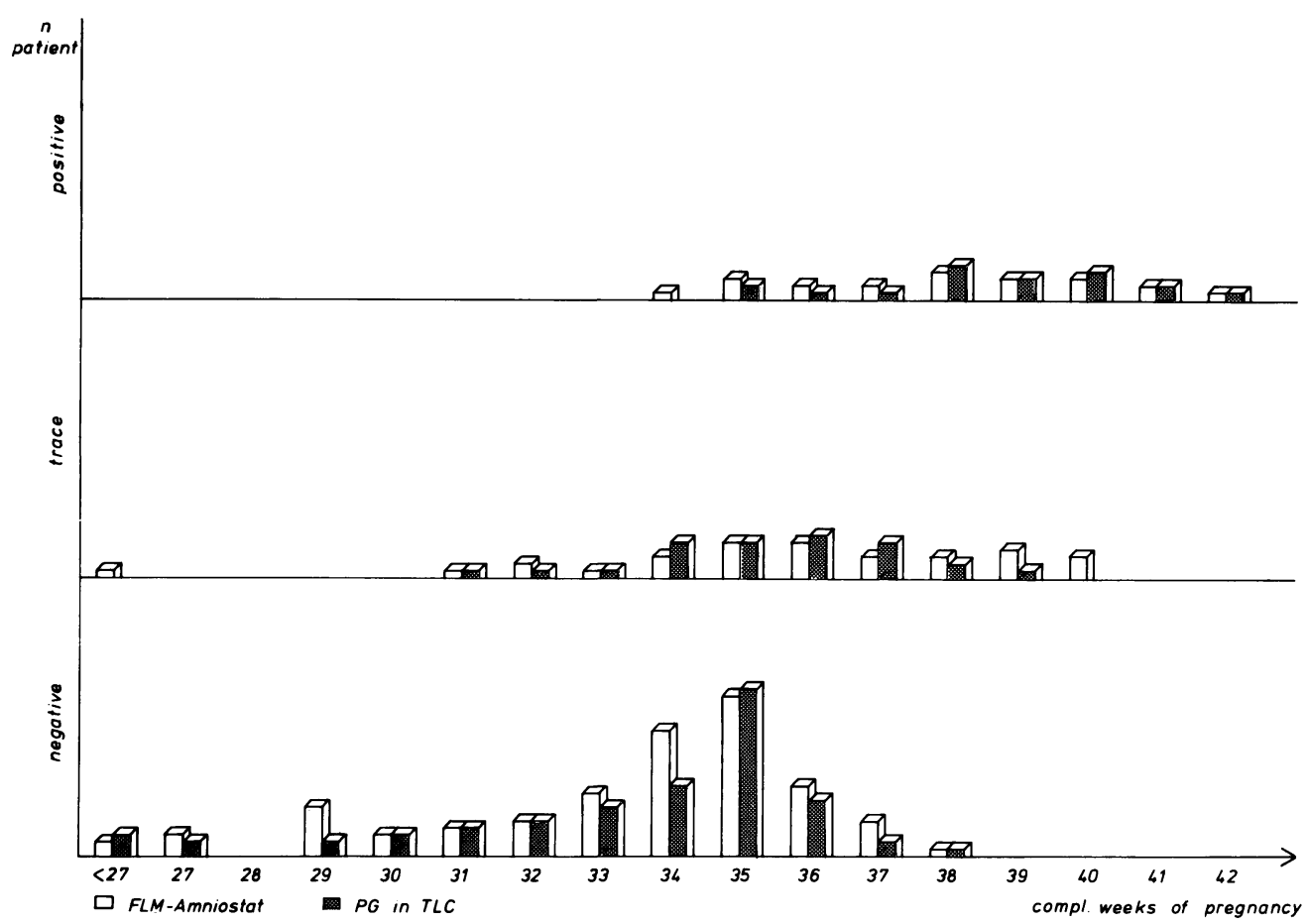

Figure 5. Semiquantitative evaluation of phosphatidylglycerol (PG) in amniotic fluid corresponding to gestational age; Determination of PG by immunological $(\square)$ or 1-dimensional sequential two step TLC ( $\square$ ).

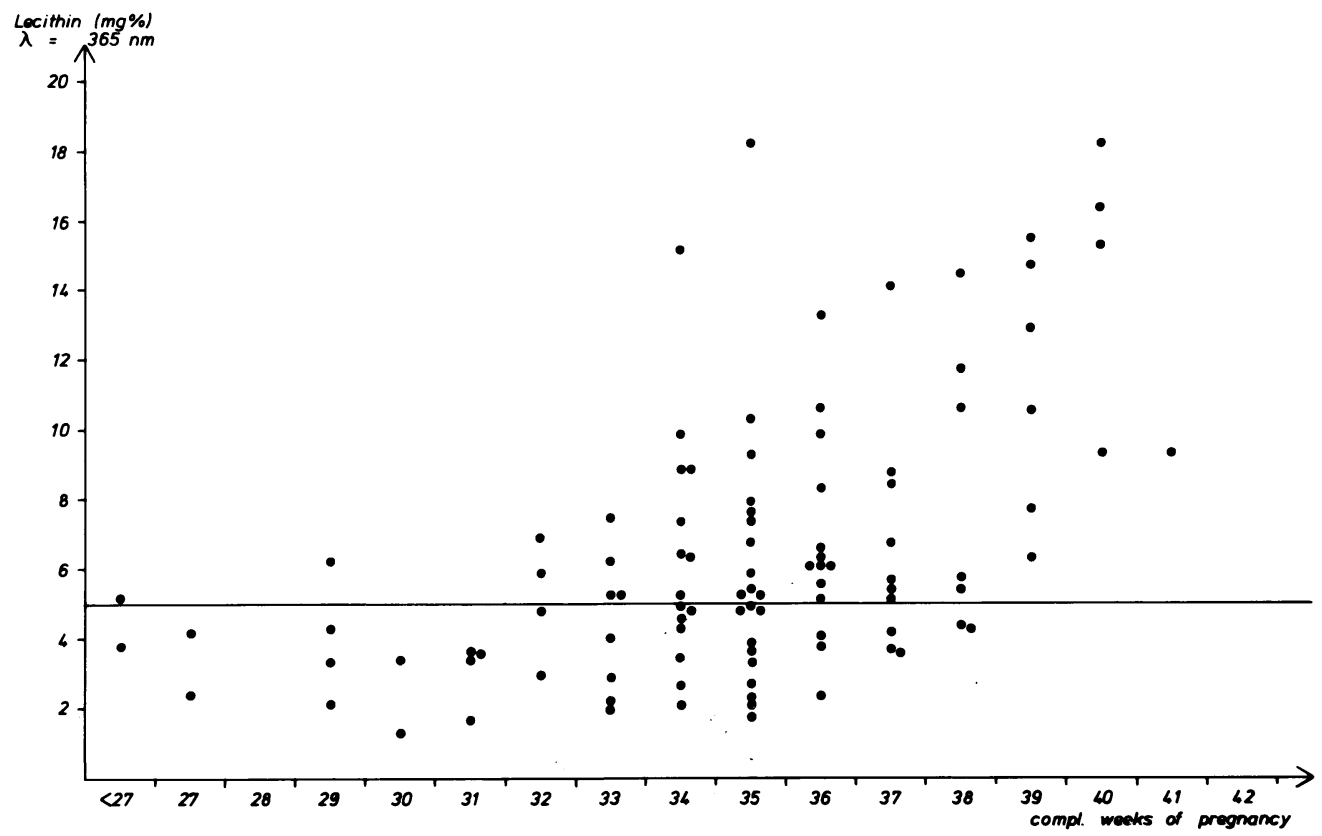

Figure 6a. Lecithin concentration (mg \%) in amniotic fluid according to advancing gestational age. Enzymatic determination of lecithin. Photometric evaluation at $\lambda=365 \mathrm{~nm}(\mathrm{Hg})$. Positive correlation of values vs. gestational age (33-39 weeks): $\mathrm{y}=0.792-21.544 ; \mathrm{r}=0.375$. 


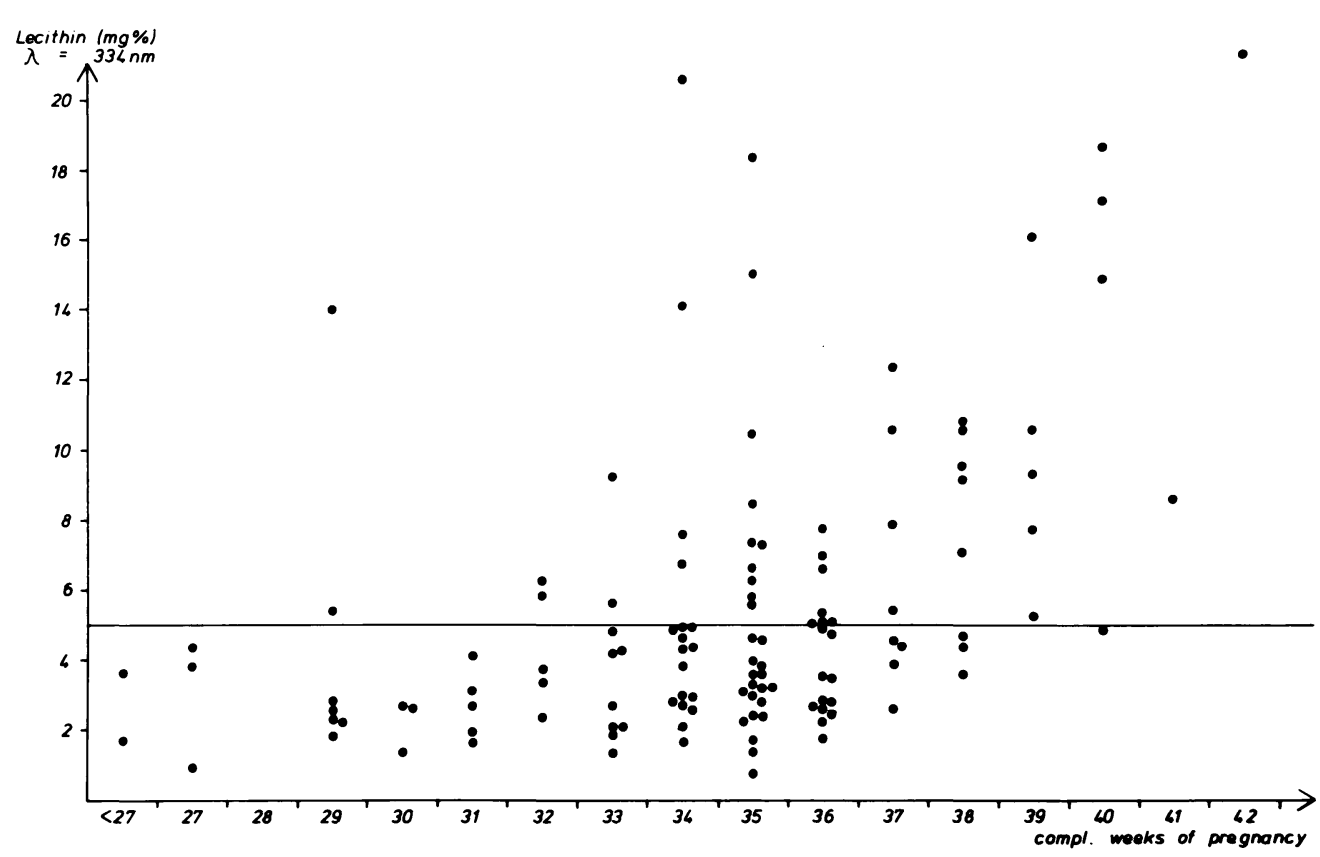

Figure $6 \mathrm{~b}$. Lecithin concentration ( $\mathrm{mg} \%$ ) in amniotic fluid according to advancing gestational age. Enzymatic determination of lecithin. Photometric evaluation at $\lambda=334 \mathrm{~nm}(\mathrm{Hg})$. Positive correlation of values vs. gestational age (33-39 weeks): $\mathrm{y}=0.75-21.248 ; \mathrm{r}=0.353$.

\section{Comment}

Insofar we can conclude that under the actual methods of amniotic fluid PL evaluation the fairly simply performable immunological PG determination as well as the one dimensional separation of AF phospholipids, which is easier to run than the original "lung profile" determination of KULO-
VICH and GLUCK [6] lead to a good information about exclusion of RDS. On the other hand below the threshold value, be it an $\mathrm{L} / \mathrm{S}$ ratio below 2 or an undetectable PG value, a discriminating parameter is lacking, which may be able to indicate the real danger of the fetus to suffer from RDS if born.

\section{Summary}

Four methods of phospholipid analysis in amniotic fluid were compared:

- miniaturized version of a one-dimensional thin-layer chromatographic determination of the lecithin/ sphingomyelin ratio [5];

- A one-dimensional thin-layer chromatographic separation of all phospholipid components in amniotic fluid [3];

- A completely enzymatic determination of amniotic fluid lecithin concentration [1, 10];

- An immunological method for semiquantitative measurement of phosphatidylglycerol [8].

The various phospholipid parameters (L/S ratio, lecithin concentration, phosphatidylglycerol detection either by thin-layer chromatography or immunological methods) show a strong correlation to advancing gestational age.

While we were not able to prove a statistically significant correlation between enzymatic lecithin values or $L / S$ ratio values and the occurrence of neonatal RDS cases in this study due to the relatively small number of RDS cases, the $L / S$ ratio values obtained by one-dimensional thin-layer chromatography and the phosphatidylglycerol values, determined either chromatographically or immunologically, showed a clear correlation to the expected development of RDS in the newborn.

Thus we can conclude that under the actual methods of amniotic fluid phospholipid evaluation immunological phosphatidylglycerol determination as well as the onedimensional separation of amniotic fluid phospholipids, which is easier to run than the "lung profile" determination of KULOVICH and GLUCK [6] provide good information about the exclusion of RDS.

Keywords: Amniotic fluid phospholipid analysis, chromatography of phospholipids in amniotic fluid, immunological determination of phosphatidylglycerol, lecithin/sphingomyelin-ratio, neonatal respiratory distress syndrome. 


\section{Zusammenfassung}

Aktueller Stand in der Diagnostik der fetalen Lungenreife Es wurden vier Phospholipidbestimmungsmethoden im Fruchtwasser miteinander verglichen:

- eine miniaturisierte Version der eindimensionalen dünnschicht-chromatographischen Bestimmung des Lezithin-Sphingomyelin-Onotientan [5];

- eine eindimensionale dünnschichtchromatographische Trennung aller Fruchtwasser-Lipidkomponenten [3];

- eine vollständige enzymatische Bestimmung der Lezithinkonzentration im Fruchtwasser [1, 10];

- eine immunologische Methode zur semiquantitativen Messung von Phosphatidylglycerol [8].

Die verschiedenen Phospolipidparameter (L/S-Quotient, Lezithinkonzentration, Phosphatidylglycerolnachweis durch Dünnschichtchromatographie bzw. immunologisch) zeigen eine enge Korrelation zum Gestationsalter. Aufgrund der relativ kleinen Anzahl von Fällen mit Atemnotsyndrom waren wir nicht in der Lage, eine statistisch signifikante Korrelation zwischen enzyma- tisch bestimmten Lezithinkonzentrationen bzw. L/SQuotienten und dem Auftreten eines neonatalen Atemnotsyndroms in dieser Studie nachzuweisen. Dagegen zeigten die L/S-Ratiowerte, die auf dem Wege der eindimensionalen Dünnschichtchromatographie bestimmt wurden, und die Phosphatidylglycerolwerte, entweder dünnschichtchromatographisch oder immunologisch bestimmt, eine eindeutige Korrelation zu der zu erwartenden Entwicklung eines Atemnotsyndroms des Neugeborenen.

Wir können feststellen, daß unter den aktuellen Methoden der Phospholipidbestimmungen aus dem Fruchtwasser sowohl die immunologische Bestimmung von Phosphatidylglycerol als auch die eindimensionale Trennung der Fruchtwasserphospholipide, die einfacher durchzuführen ist als die Bestimmung des „lung profile“ nach KulovicH und GluCK [6], eine gute Information hinsichtlich des Ausschlusses eine drohenden Atemnotsyndroms des Neugeborenen geben.

Schlüsselwörter: Atemnotsyndrom des Neugeborenen, Chromatographie der Phospholipide im Fruchtwasser, immunologische Bestimmung des Phosphatidylglycerol, Lezithin-Sphingomyelin-Ratio, Phospholipidbestimmungsmethoden im Fruchtwasser.

\section{Résumé}

État actuel du diagnostic de maturité pulmonaire foetale On compare quatre méthodes d'analyse des phospholipides dans le liquide amniotique:

- Version miniaturisée de la détermination du rapport Lécithine/sphingomyéline par chromatographie unidimensionelle en couche mince [5];

- Séparation par chromatographie uni-dimensionelle en couche mince de tous les phospholipides du liquide amniotique [3];

- Dosage de la lécithine dans le liquide amniotique par méthode enzymatique totale $[1,10]$;

- Détermination semi-quantitative du phosphatidylglycérol par méthode immunologique [8].

Les différents paramètres phospholipidiques (rapport L/ $\mathrm{S}$, taux de lécithine, déterminations du phosphadidylglycérol que ce soit par chromatographie en couche mince ou par immunologie) sont fortement corrélés avec l'augmentation de l'âge gestationnel. Bien que nous ne soyons pas capables de prouver une corrélation statistiquement significative entre les valeurs de la lécithine par méthode enzymatique ou les valeurs du rapport $\mathrm{L} / \mathrm{S}$ et la survenue du SDR néonatal dans cette étude du fait du nombre relativement faible de SDR, toutefois les valeurs du rapport $\mathrm{L} / \mathrm{S}$ obtenues par du nombre relativement faible de SDR, toutefois les valeurs du rapport $L / S$ obtenues par du nombre relativement faible de SDR, toutefois les valeurs du rapport $\mathrm{L} / \mathrm{S}$ obtenues par chromatographie uni-dimensionelle en couche mince et les taux de phosphatidylglycérol, trouvés soit par chromatographie soit par méthode immunologique, montrent trouvés soit par chromatographie soit par méthode immunologique, montrent une corrélation nette avec le risque de développement d'un SDR pour le nouveau-né.

Aussi, pouvons-nous conclure que sous couvert des méthodes actuelles d'étude des phospholipides du liquide amniotique qu'il s'agisse de la détermination immunologique du phosphatidylglycérol ou de l'étude des phospholipides du liquide amniotique par chromatographie uni-dimensionelle qui est plus aisée à réaliser que la détermination du "profil pulmonaire" de Kulovich et GLUCK [6], nous pouvons abtenir de bonnes informations concernant l'élimination du risque de SDR.

Mots-clés: Analyse des phospholipides du liquide amniotique, chromatographie des phospholipides dans le liquide amniotique, détermination immunologique du phosphatidylglycérol, rapport lécithine/sphingomyéline, syndrome de détresse respiratoire néonatale. 


\section{References}

[1] Diedrich K, SE Evans, HJ Gibitz, AR Helbing, G Kynast, T HeINZE, B LiedTKe, U LORENZ, G MARTENS: Enzymatische Lezithinbestimmung im Fruchtwasser zur antepartalen Lungenreifediagnostik - eine multizentrische Studie. Z Geburtshilfe Perinatol 186 (1982) 19

[2] Farrell PM, ME Avery: Hyaline membrane disease. Am Rev Respir Dis 111 (1975) 657

[3] GIPs H: Personal communication (1986)

[4] GLUCK L, MV KuLOVICH: Lecithin / sphingomyelin ratios in amniotic fluid in normal and abnormal pregnancy. Am J Obstet Gynecol 115 (1973) 539

[5] GluCK L, MV Kulovich, RC BORER, PH BRENNER, GG ANDERSON, WN SPELLACY: Diagnosis of respiratory distress syndrome by amniocentesis. Am J Obstet Gynecol 109 (1971) 440

[6] Kulovich MV, L Gluck: The lung profile. II. Complicated pregnancy. Am J Obstet Gynecol 135 (1979) 64

[7] Leucht W, H Heyes, K Musch: Correlation of the procoagulant activity in amniotic fluid to gestational age and fetal pulmonary maturity. Prog Respir Res 15 (1981) 126
[8] Lockitch G, BK Wittmann, SM Mura, LC HawKLEY: Evaluation of the amniostat - FLM assay for assessment of fetal lung maturity. Clin Chem 30/7 (1984) 1233

[9] LORENZ U: Antepartale Lungenreifebestimmung durch Fruchtwasseranalyse. Springer, Berlin Heidelberg - New York 1982

[10] LORENZ U: Enzymatische Bestimmung der Lecithin-Konzentration im Fruchtwasser zur antepartalen fetalen Lungenreifebestimmung. Z Geburtshilfe Perinatol 190 (1986) 141

[11] RütTgers H, U LORENZ, W LeUCht, J WinkLeR: Lezithin-Bestimmung aus dem Fruchtwasser durch Messung der Oberflächenaktivität. In: DuDENHAUSEN JW, E SAlING (eds): Perinatale Medizin, Bd. VI. Thieme, Stuttgart 1975

[12] SCARPELli EM: The lung, tracheal fluid and lipid metabolism of the fetus, Pediatrics 40 (1967) 591

[13] SCARPELLI EM: The surfactant system of the lung. Lea \& Febiger, Philadelphia 1968

Prof. Dr. Uwe Lorenz

Universitätsklinikum Steglitz der FU Berlin

Frauenklinik und Poliklinik

Hindenburgdamm 30

1000 Berlin 45, West Germany 


\section{de Grutter References}

\section{NEW, COMPLETELY REVISED THIRTEENTH EDITION American Universities and Colleges}

\section{Produced in collaboration with the American Council on Education}

1987. $21 \times 27.5 \mathrm{~cm}$. XX, 2040 pages. With numerous charts and tables. Cloth DM 298,-- ISBN 3110109026

American Universities and Colleges is published every four years. We invite standing orders.

Based on a new survey begun in September 1986, this completely updated and expanded edition of American Universities and Colleges continues the tradition of being the foremost reference book on postsecondary education in the United States. Prepared in collaboration with the American Council on Education, the major coordinating body of higher education, the revised Thirteenth Edition provides the most comprehensive collection of information on accredited institutions offering baccalaureate degrees and above.

The Thirteenth Edition is enlarged both in the number of institutions represented and the amount of information provided. Over 1,900 institutions are covered, including 125 new institutions recently accredited.

American Universities and Colleges provides both the essential statistical data (tuition, room, board, admissions requirements, financial aid, enrollments, etc.) and all the other information equally important to decision making (student life, library holdings, physical plant, accelerated and study-abroad programs, etc.).

A full section is devoted to the foreign student in U.S. institutions. Included is a list of overseas offices with counseling services on study in the U.S., plus a number of tables dealing with various aspects of foreign student enrollments from 1954-55 to 1985-86.

Another section deals with professional education in the U.S., using nearly 40 subject areas to discuss the institutions offering professional programs, admission and degree requirements, and licensing and certification programs. Other sections deal with such diverse topics as the history of higher education in the U.S. and the academic costume code.

\section{From reviews of the Twelfth Edition:}

"To sum up these five guides ... no high school, public, or academic library reference collection is adequate without AUC."

Choice

"The new edition continues the tradition of completeness ... No other general purpose college guide offers similar coverage ... belongs in every academic, public, and high school library, for it provides perspectives on colleges other guides do not even consider." Wilson Library Bulletin

\section{de Gruyter · Berlin · New York}

